\title{
COMPARATIVE ECONOMICS, GLOBALISATION AND THE EUROZONE IN THE QUEST FOR A NEW EUROZONE PARADIGM
}

\author{
DALLAGO, Bruno
}

The Eurozone is at a crossroads. Its neoliberal and ordoliberal construction proved to be unworkable and, after the crisis, made the macroeconomic adjustment slow and costly - causing financial and real divergence among the member countries. Kolodko's writings offer interesting insights. This article considers Kolodko's study of Poland and Greece and adds two other paradigmatic cases, those of Germany and Italy. Kolodko's case studies and criticism of neoliberalism lead him to propose a New Pragmatism in policy making. This proposal offers important insights, but neglects two fundamental problems: moral hazard and institutional differences. These have to be included in the New Pragmatism to give this the strength and ability to contribute to solve the Eurozone problems.

Keywords: Eurozone, Germany, Greece, institutional differences, Italy, moral hazard, neoliberism, ordoliberalism, New Pragmatism, Poland

JEL classification indices: E02, E63, E65, F36, F45, G01, 052

Dallago, Bruno, Professor at the Department of Economics and Management, University of Trento. Guest lecturer at Berkeley, the University of North Carolina and Kyoto University, as well as member of the External Counselling Body of the Hungarian Academy of Sciences.

E-mail: bruno.dallago@unitn.it 


\section{INTRODUCTION}

The deepening of the process of European economic and monetary integration is one of the great transformations that characterizes the European continent since the final part of the $20^{\text {th }}$ century, the second one being transformation in Central and Eastern Europe. Although ideally and politically distinct and technically different, these two great events and processes overlap in part and have clear and important mutual influences.

The mainstream neoliberal approach to both processes is clear, simplified and nearly mechanical. While it considers that institutions matter, it limits concern to only formal institutions: in particular, property rights and political institutions in the case of transformation and fiscal discipline and money in the case of European integration. Moreover, the role of institutions is based on the faith that a free and competitive economy develops spontaneously once fundamental formal institutions (a private property regime and liberalization) are fixed through political and legal action. Moreover, well working competitive markets would sprout up automatically once constraints are eased. A necessary requirement is that policies should not try to manage the economy, but be limited to guarantee the basic conditions for the natural free market interaction of rational actors, in particular, balanced budgets and a non-inflationary supply of money, along with law and order. Both processes have the Washington Consensus as their leading recipe.

The fundamental problem with this approach is that it assumes that European integration and transformation are normal events. This belief was a dangerous and costly illusion. Although different, the two cases share the essence of any process of transformation: the change of the economic system and economic structures. It is not only single elements that change: even more important, it is the interaction and coordination among these elements that is radically transformed (Dallago 1996).

During his remarkable and long academic/political activity, Kolodko provides a clear criticism of the neoliberal approach, based on sound non-standard research and an exceptionally wide and deep knowledge and experience of policy management. He also advances ideas and sound reasoning that are worth considering carefully to find inspiration and advice. In this paper I concentrate on the Eurozone (EZ), with scattered hints to the transformation process to avoid blurring the important differences and requirements of the two processes. I will use Kolodko's contribution to the analysis of some critical issues as a guideline, to find an answer to the present difficulties of the Eurozone.

The next section considers neoliberalism as the fundamental cause, according to Kolodko, of the negative consequences of globalisation and the build-up of the EZ. Section 3 reviews three paradigmatic national cases in the EZ and shows the 
complexity of the situation that includes, but goes beyond the neoliberal dominance in policy making. Section 4 is devoted to Kolodko's New Pragmatism approach to policy making and considers how this approach could get operational strength. Section 5 concludes.

\section{THE MAINSTREAM CONSTRUCTION OF GLOBALISATION AND THE EUROZONE}

The theoretical and ideological orientation of economists has played a prominent role that was often covered by its pretended scientific nature and that influenced the action of practical men. Or perhaps practical men hide their interests and goals under the pretended scientific cover of men of thought and science. ${ }^{1}$ Kolodko places great relevance to the combination of theoretical ideas and ideologies with practical interests. When this intermingling leads to bad policies, chances are that societies pay a high price, whose burden is distributed asymmetrically, to the advantage of those who can manage policies and economic processes.

This interpretation is important for explaining the origin of the 2008 international crisis and the crisis of the European monetary union. The international crisis, according to Kolodko, is a systemic crisis of modern capitalism, and in particular of its neoliberal mutation and "...more the crisis of redistribution rather than of production” (Kolodko 2010: 4). The roots of the crisis go back in the long run, to some three decades ago, when it was still possible to steer the world economy (and the European integration and transformation in Central-Eastern Europe) away from the dangerous waters of neoliberalism and towards the sounder and firmer path of the social market economy (in German: Soziale Markwirtschaft).

There are various reasons why neoliberalism is dangerous for the stability and prosperity of an economy. "Neoliberalism facilitated the creation of a peculiar 'casino economy'. It means the detachment of the financial sector from the real economy and pulling increasingly larger economic and social circles into the whirlpool of speculations” (Kolodko 2010: 10). Particularly important for causing the crisis was the gradual weakening of the state and deregulation. Under these conditions, alternative policies can do little good and are essentially a reaction to the symptoms and consequences of the crisis. Fixing problems and fostering

1 On the last page of his General Theory, Keynes famously wrote that "Practical men who believe themselves to be quite exempt from any intellectual influence, are usually the slaves of some defunct economist. Madmen in authority, who hear voices in the air, are distilling their frenzy from some academic scribbler of a few years back". Yet this quotation can also be turned upside down, in that "...defunct economists - and their theories - are usually enslaved by practical men who do not fully understand them” (Bini Smaghi 2010). 
sound development requires much more and much deeper changes, down to the systemic sources of the crisis, in particular changing the value system, re-orientating institutions and changing the way of conducting policies.

This explanation is useful to interpret the construction of the Eurozone and its evolution, particularly when enriched with additional factors accounting for the apparent contrast of the EZ with the social market economy prevailing in many of its member countries, in particular in Germany. The EZ was built on the principles of neoliberal economics and German ordoliberalism. ${ }^{2}$ However, it remained institutionally incomplete because of the unwillingness and inability of other member countries to proceed straight to political unification. The chosen way relied on fiscal convergence through the discipline of convergence parameters. In this way, national finances would not jeopardize the solidity of the common currency and efficient markets would solve the problem of financing investments and growth through a kind of private insurance mechanism ${ }^{3}$. The context within which the EZ institutional architecture was built was that of globalization, which brought advantages but also constraints (e.g. as defined in the impossible trinity theorem). ${ }^{4}$

2 Ordoliberalism was the leading economic and social thought at the basis of the social market economy established in Germany after World War II. It can be considered a variant of neoliberalism in which, in contrast with laissez-faire liberalism, the conditions for a free market economy are guaranteed by the authority and action by a strong state. Ordoliberalism depicts a form of state-centric liberalism, in which the strong state is the political form of free markets, and competition and enterprising are political tasks. Economic freedom is a fundamental tenet of ordoliberalism, but economic freedom is ordered freedom. Along with law and order, among the necessary conditions are also social policies. These aim at including and captivating workers and making them participate in the economy also as depositors of property rights, both as private owners and through co-determination. This aim is addressed also to avoid the radicalisation of trade unions and workers' political movements (Bonefeld 2012, 2013; Schnyder - Siems 2013). This German idiosyncrasy is at the basis of the position that Germany consistently held and successfully imposed on European institutions during the crisis (Dullien - Guerot 2012; Young 2014).

3 Integrated capital markets offer an alternative mechanism that can be compared to a private insurance system, since the mobility of capital allows for automatic insurance against shocks if capital flows where there is more need, i.e. to deficit countries. Thus the private insurance mechanism consists of the flow of resources from countries with strong financial situations to countries in more vulnerable conditions. This mechanism worked apparently well until the international crisis started, but often went to finance unproductive expenditures and speculative operations and constructions in the real estate, which strongly contributed to the build-up of real estate bubbles in the EZ periphery.

$4 \quad$ The impossible trinity or trilemma (Obstfeld et al. 2004; Baldwin - Wyplosz 2012) illustrates the impossibility for an open economy to pursue at the same time the three fundamental policy objectives: a fixed exchange rate, free capital movement, and an independent monetary policy. The trilemma is based on the condition of interest rate parity and is supported by empirical studies, providing substantial evidence of failures when governments tried to pursue the three 
Kolodko and many others explain the prevalence of this approach with the increasingly dominant neoliberal ideology and the interest of the dominant political and economic circles. However, this view does not explain why the social market setting served well those interests at the national level in Germany and other continental countries, but failed to play a similar role in the monetary unification. The dominant intellectual and academic role of neoliberalism over ordoliberalism, the intellectual basis of the social market economy, played certainly a role. Similarly, important was that various EZ member countries, including France and Italy, were largely alien to the ordoliberal views and practice. Yet quite important was the lack of trust among the founding countries of the monetary union.

Inter-governmental trust explains why these countries decided to adopt a common currency that neither of them could control, thus denominating their finances and particularly their debts in an alien currency. However, the financial stability of a monetary union required setting up an institutional system that constrained the policy freedom of national governments and engaged credibly the latter to implement easily controllable achievements. Neoliberalism offered an easier and effective solution in terms of fiscal discipline and convergence parameters. The social market solution would have been much more complex and not easy to implement in countries with different economic systems and different degrees of political, administrative and technical capabilities of national states. Moreover, the social capital needed for a well working social market economy did not exist in various member countries. The neoliberal approach promised also to compensate the disadvantaged countries with the rapid decrease of interest rates through the monetary unification. This allowed these countries to recover the resources needed to finance the necessary reforms for keeping financial discipline.

Thus a potentially disruptive conflictual situation was elegantly transformed into a simple, bureaucratic exercise of control. The fundamental weakness of this solution is that it misled EZ authorities and member countries to believe that it could work without a complete institutional architecture and based on the willingness of member countries and the enforcement by common organs. Any discrepancy in the local situations could have been smoothed away and solved by the private insurance mechanism. EZ and national authorities where certainly

objectives at the same time. Under these conditions, policy authorities can only pursue two of the three objectives simultaneously and can consequently use only two of the related policies. The Eurozone chose to have an independent monetary policy and allow for free capital movements, while its member countries keep a fixed exchange rate and free capital movements and their national central banks cannot have an independent monetary policy. At the same time, the ECB has an independent monetary policy, which includes the ability to set interest rates independently, with free capital movements. However, the ECB cannot fix exchange rates and the euro is part of an international floating exchange rate system. 
myopic and short-sighted and the dominant neoliberal paradigm played certainly an important role in leading to this result. Yet alternatives promised to be complex and politically difficult.

Markets trusted this construction for years. Money flowed abundantly to countries in need to finance investments to foster growth and with unbalanced finances. Yet there were two problems. First, the flow was fundamentally based on a misunderstanding: i.e. that there existed an (implicit) common umbrella protecting all member countries, in spite of the draconian treaty articles forbidding such common financing (in particular the no-bailout clause, in article 125 of the Lisbon Treaty, and the prohibition of monetary financing of article 123). Second, much of the inflow of resources was used unproductively to inflate real estate bubbles. In addition, wages in vulnerable countries converged to the level of EZ richer countries and pulled a strong expansion of consumption. At the end, real estate and consumption bubbles were the main engines of dynamic growth in a number of countries, such as Greece, Spain, Ireland and Cyprus.

This was an artificial and unsustainable process, because little was invested in productive sectors and productivity either stagnated or fell in these economies. When the international crisis made clear that adjustment of distressed finances and economies would be a national affair of the distress countries, markets reacted. A sudden stop of financial flows ensued and the reverse process dominated soon: money started to leave distressed countries and flowed to resilient countries, first among which was Germany. Interest rates increased rapidly in the former, while real interest rates became negative in the latter. This created strikingly different situations in member countries for financing both public budgets and companies. The latter effect contributed to distorted competition within the EZ. Following austerity policies and internal devaluation, the public deficits and debts of distressed countries increased further through the fiscal multiplier effect (Blanchard - Leigh 2013). ${ }^{5}$

The ensuing increase of public debts in vulnerable countries was entirely due to the dramatically increased value of the fiscal multiplier (Nuti 2013). Vulnerable countries lost the resources that should have been used to support the economy, while the enforcement of convergence parameters prevented countries from financing public expenditure through deficit. The hard financial discipline imposed by the EZ, together with the substantial financial easing in the United

5 An important role played the idea of expansionary austerity, or more precisely the Expansionary Fiscal Contraction (EFC) hypothesis, proposed originally by Giavazzi - Pagano (1990), based on the study of fiscal restructurings of Denmark and Ireland in the 1980s. According to the quoted paper, overall economic expansion can derive from a major reduction in government spending that expands private consumption, when this changes future expectations about taxes and government spending. 
States strengthened the value of the euro against the dollar. This further complicated the situation of distressed countries through the export channel, until the ECB successfully weakened the strong euro since 2014.

Austerity policies became a general mantra for all countries out of line with the convergence parameters. The very limited pragmatism used to take "exceptional circumstances" of the countries' situation into account was insufficient to support those countries in regaining financial stability, let alone growth. What really mattered was the political will to discipline vulnerable countries to avoid jeopardizing the stability of the euro and the financial situation of resilient countries. Interestingly, such worry did not apply to private finances, whose consideration would have changed, sometimes dramatically so, the degree of vulnerability and resilience of countries.

The perverse interaction between the incomplete and unbalanced construction of the EZ and the use of rigid austerity policies based on the wrong analysis of the economic situation and biased theories out of line with the institutional and real conditions have a price. In spite of years of mildly positive fiscal stance in the EU and EZ (EC 2016), GDP in various EZ countries is still below the precrisis level, investments are stagnating, productivity is depressed, unemployment high (especially youth unemployment), incomes and welfare low, inequalities are high. However, it was also the worry for moral hazard fuelled by national idiosyncrasies and shaky political wills that rendered the situation particularly damaging and so resilient to any critical appraisal and change of strategy.

The problem now to understand is what is to be done. Is it sufficient to fix the mistakes, in particular to change the theoretical reference and, consequently, policies? Was anything fundamental forgotten or overlooked in the institutional construction of the EZ and can anything be done to improve the situation?

\section{GREECE AND THE OTHERS}

A better understanding of the EZ problem comes from considering comparatively three paradigmatic cases: those of Germany, Greece and Italy. Germany was, according to The Economist, the sick man of the euro as recently as early as $1999 .{ }^{6}$ A few years later, Germany became the repository of the EZ orthodoxy and sound fiscal management: fiscal discipline, austerity policies and internal devaluation. In between there were the Hartz reforms of 2003 and 2004 (restructuring labour market relations), which dramatically changed the situation of Germany (Möller

6 In 1999, The Economist labelled Germany as the "sick man of the euro" (https://www.economist.com/node/209559). 
2016). They were implemented at the right moment: when financial markets were relaxed and confident, capital was abundant and cheap, and time to reform was ample. This gave Germany a kind of competitive advantage over countries, such as Greece and Italy, which failed to reform in due time, when it was easier and cheaper. Yet it must be recognised that political courage and determination was essential, even at the risk of unpopularity. Indeed, the SPD's Schröder government lost the following elections in 2005 and remained out of government since then, except as a junior partner in the two grosse Koalitions headed by Angela Merkel.

Since then, Germany over-fulfilled the implementation of convergence parameters, thus playing a pro-cyclical role that went to the disadvantage of other countries in distress and in need of external indirect support. The main issue is the accumulation of huge current account surpluses since 2011, consistently above the European Commission's indicative threshold of $6 \%$ of GDP (Zoppè 2018). For this, the country had the very mild trouble of being investigated under the Macroeconomic Imbalance Procedure since 2014. This looks much as a de facto beggar-thy-neighbor policies á-la-Eurozone. Kolodko is right in blaming Germany for its uncooperative attitude and its lazy compliance with EU laws?

The case of Greece is radically different. Greece entered the European Union only in 1981 and was accepted as a EZ member in 2001, in spite of open doubts about the reliability of its financial accountancy. Book forging was extensively used in the years before EZ membership. The newly elected Papandreu government admitted the forging and revised substantially estimates of public deficit in 2009 (see the details later). The timing was ill-chosen. In Fall 2009, the international crisis reached its climax and forcefully hit the EZ. Markets were nervous and the German government was under the pressure of a vociferous media and public opinion in view of the federal elections at the end of September 2009. Moreover, it became evident that the EZ did not possess adequate instruments for dealing with financial distress of its member countries. ${ }^{8}$

In May 2010 a "troika" (EU, IMF and ECB) meeting in Brussels decided to set up a $€ 110$ billion support plan for Greece, under the surveillance of the troika itself. In the meantime, the situation worsened and, following the S\&P downgrade of Greek sovereign debt titles to junk bonds, the country was virtually in default. The uneasy and confused management of the Greek crisis - whose initial cost

7 Germany (together with Spain) had the highest number of open infringement cases (91), as of 31 December 2016 for violation of EU laws (EC 2017).

8 These instruments were developed only later, learning also from the Greek crisis, and mainly thanks to the ECB's determination, such as the European Financial Stability Facility (EFSF, created in June 2010) and European Stability Mechanism (ESM, in operation since October 2012). 
was estimated at only €30 billion - caused contagion spreading to other countries $^{9}$, although in Cyprus, Ireland, Portugal and Spain the situation was entirely different from Greece.

The fiscal and real situation of Greece continued to worsen and the May 2010 bailout could only be the beginning. In July 2011 an agreement was reached among creditors to extend a second support package and implement a major "haircut" of 53.5\% of private credit (primarily German, French and Dutch banks, which in previous years bought abundantly Greek bonds). ${ }^{10}$ The involved value was of $€ 240$ billion. The new support credit was defined in February 2012 at $€ 130$ billion and was added to the first support credit of May 2010. The credit was accompanied by draconian conditionalities in terms of austerity policies and public expenditure cuts. During the negotiations a major conflict erupted between the IMF - which insisted for cutting part of the Greek debt - and European creditors, which refused to do so.

The climax of the Greek saga was reached in Summer 2015. At the beginning of that year a new government was formed following the electoral victory of Syriza party. The government took a confrontational attitude to the troika and a clear opposition to the continuation of austerity policies. After having obtained a nearly two-thirds majority in a referendum organised for rejecting the conditionalities, a dramatic confrontation took place between the Greek government and the troika representatives. The agreement reached on 14 August included support for €86 billion, additional to the previous two packages, included tough conditionalities, but did not consider the question of the sustainability of the Greek debt.

Since then, Greece progressively disappeared from the EZ black news. The country started a dramatic process of reforms, cuts and sacrifices, including a massive plan of privatization, so far implemented only in a modest part. Greece still has a weak economy, with little and uncompetitive industry, with considerable rent-seeking and tax evasion. The cost of adjustment was economically and socially heavy: by 2018 GDP is down by $25 \%$, pensions were cut 13 times (a $14^{\text {th }}$ one will ensue on 1 January 2019), poverty and unemployment are widespread, migration of the young and skilled is worrying (at 500,000).

All in all, reforms were partially successful in improving the situation and support packages helped. The three packages amounted overall to a support of $€ 326$

9 All this happened in spite of the fact that Greece is a small country. The Greek GDP is $0.27 \%$ of the world GDP and just 1.2\% of the EU GDP and 1.6\% of the Eurozone GDP.

10 Germany and France decided not to implement the haircut, in order to avoid the need to intervene to bailout their own banks, which would have afforded massive losses. Intercountry public support and the implementation of austerity policies by the Greek government allowed the ECB to intervene in the secondary market to buy Greek bonds that private banks, mainly of Germany, France and the Netherlands were selling massively. 
billion, more than 10 times the originally estimated cost of adjustment. Most of the actually dispensed support - €273.7 billion - was provided by EZ countries (€241.6 billion). Greece implemented 450 reforms overall during the last three years, the privatization program has moved the first steps, with $€ 6.8$ billion revenue overall since 2016, out of a planned $€ 50$ billion (Da Rold 2018). Recently, the economy has shown signs of recovery from its deep trough: GDP yearly growth was $1.4 \%$ in 2017 and is foreseen to increase further to $1.9 \%$ in 2018 and $2.3 \%$ in 2019. Public finances appear to be stabilized: budget deficit, which was at $15.1 \%$ in 2009, the highest in the EU, now displays a surplus at $+0.8 \%$. The primary budget showed a surplus of $4.2 \%$ in 2017. Yet public debt increased further at $179 \%$, the highest in the EU.

A positive development occurred in August 2018, when the bailout process expired and Greece returned to the international credit market. This was made possible by the Eurogroup resolution of 22 June, which also included the 10-year postponement of the overdue payment of €96.8 billion debt. Moreover, Greece obtained a loan of $€ 15$ billion to form a $€ 24$ billion cash buffer. Yet Greece did not obtain a precautional credit line from the IMF to afford the uncertainty and risks of the transition phases, but remained under strengthened observation. Moreover, the IMF did not contribute to the third support credit, because it failed to obtain that the sustainability of the Greek debt was afforded and solved.

On top of this, many Greeks suffered massively, without relief so far. Overall, the Greek exercise was an extremely costly attempt to get rid of moral hazard in the EZ, absent the ability to institutionalize cooperation in the EZ to deal effectively with distress and bailouts. Was it successful or was it useless? Could it be beneficial to Greece in the long run? Were there better ways to reach these results?

In Kolodko's view, the troika "...has a much greater share of responsibility for the crisis than Greece", also because EU authorities "turned a blind eye to the structural and institutional weaknesses and to some statistics being manipulated" (Kolodko 2016a: 48). However, responsibilities for the Greek crisis shifted through time from the Greeks to the troika: "In the initial phase of the crisis, when Greece's public debt approached 100 percent of GDP, essentially the Greeks were to be blamed, because they had been living beyond their means. For the subsequent explosion of the crisis and its present culmination far more than the Greeks themselves responsible is the rich West, with its banks and financiers, with its incompetent politicians and biased technocrats" (Kolodko 2016b: 17-18).

This statement is fair and important when considering what should be done, in particular in the case of the Greek debt. Clearly, a change in the troika stand is fundamental, yet not enough and the Greeks should also do their part. They 
should go through a tough financial program and appropriate changes in the functioning of the economy in exchange for debt relief. This conclusion brings a fundamental teaching for what is necessary to do to fix the EZ conundrum. Yet Eurozone's institutional incompleteness has its price. I'll return to this important issue in the conclusions.

Kolodko makes an interesting point of "...certain analogies between the present harsh stance against Greece and the attempts to impose a similar policy on Poland in the mid-1990s. Some external centres, ranging from the then orthodox International Monetary Fund, and our local home grown neoliberals - as if not disgraced enough by the failure of their shock without therapy - both called for similar moves. ... However, back then, it was possible to effectively resist such pressures by implementing a proper program of structural reforms and sustainable development - the 'Strategy for Poland'”. (Kolodko 2016a: 41)

There are two points that Kolodko's approach fails to consider convincingly. The first point concerns the nature of banks. Banks have to keep the confidence of millions of savers, along with that of their major customers. This requires that they have to give priority to the interest of their clients. Requiring, correctly, that authorities should protect the latter (Kolodko 2016b) is not sufficient. Second, the comparison of the Greek and Polish cases overlooks important economic, geostrategic and political differences, which contribute to explain why the Polish debt was in part written off various times, while the Greek debt was not (see also Kolodko 2017b). When the first write-off waves took place ${ }^{11}$, Poland was still a socialist country allied to the Soviet Union, but was politically unstable, had a strong organized domestic opposition and enjoyed the support of a sizeable Polish émigré lobby in the United States. Financial support in the form of writing off part of its debt with both Western private banks and governments was more a political decision than an economic one, although the Polish market looked promising in perspective. Moreover, international financial markets had abundant capital that could be offered at favourable conditions. Politics, then, played a much more important role than with Greece.

The second write-off took place in 1993-1994, when transformation was proceeding fast and Kolodko was the vice-prime minister and minister of finance of Poland. Supporting Poland meant supporting the process of transformation into a capitalist market economy, and a new political and military ally to the West. Moreover, Poland was a rapidly expanding mid-size market, placed in a critically important geo-strategic location and international financial markets were quite liquid and had the support of governments.

11 Poland obtained seven reschedulings of its commercial bank debt and five reschedulings of its sovereign debt between 1981 and 1990 (Cohn 2012). 
Nothing of this held in the case of Greece and capital markets were still under the negative influence of the international crisis. Moreover, Greece had a further disadvantage: it could be accused of having deceived the good faith of partners and mutual trust by blatantly forging financial statistics, thus revealing the potential threat of moral hazard. This behaviour was clearly against the prevailing neoliberal and even more so ordoliberal dogmas and related policies. While Poland was working to the advantage of those ideology and institutions, also in the political, geostrategic and social arena, Greece was threatening them in the economic domain and defying them in the other arenas, in particular through the proposal and implementation of unwelcome (in Brussels, Berlin and Washington) referenda. Poland was a new friend, Greece was a potential new foe, and, in addition, a weak one. Thus the attitude of the EZ and the orthodox IMF was rational, yet short-sighted and horribly expensive in both economic and social terms. It was economically inefficient, to both Greece and the EZ taxpayers, socially nasty, but perhaps not totally negative in the long run for the cohesion of the EZ and the stability of financial markets. Again, ungoverned globalization and EZ's institutional incompleteness have their price, that the weak is called to pay.

Italy again is in a different situation. The country never needed any bailout, in spite of its prolonged crisis. One of the industrial powerhouses of the EZ, the country witnesses stagnating labour productivity since mid-1990s and decreasing from some $20 \%$ above the EU average to below the average. Once a powerful exporter with a world market share of $4.3 \%$ in early 1990s, exports receded to $2.3 \%$ presently. In spite of this and after years of substantial current account deficits during the years of the crisis, the country reached a surplus since 2013 by mainly restraining imports, but also through some success of exports. During the crisis, Italy lost most of the once powerful large enterprises, both because they went bankrupt or left the country and because the state - which owned and run traditionally various successful and competitive large companies - withdrew from active industrial activity, following large-scale privatization in early 1990s.

GDP growth was negative for years, so much so that presently, after nearly four years of mild growth - albeit below the EZ average - overall GDP is still below the pre-crisis level. Austerity policies were mildly effective in keeping public finances under control and internal devaluation succeeded in keeping Italian goods competitive in the market in spite of ailing investment and innovation. Yet unemployment remains high and migration of the young and skilled people is a problem for the country and its development perspectives. Although financial management of public finances was effective - budget deficit was always below 3\%, except in 2009 and Italy avoided the corrective arm of the SGP - the ailing GDP caused a continuing, albeit slow growth of the debt over GDP, the second highest in the EZ after Greece. 
Looking for the reasons of this dismal and creeping, albeit not dramatic crisis of Italy - which may lead to a long-term deindustrialization and economic decadence - and confronting it with Germany and Greece, what is striking is the uncertain path of reforms. Moreover, in a relatively large economy - an economy in which nearly $4 / 5^{\text {th }}$ of aggregate demand is internal -, austerity policies inevitably shrink internal demand more than the growing external demand helped. Internal devaluation, which decreases wages, pensions and welfare and weakens labour incentives, are contrary to innovation. Firms find more convenient to replace costly machines and equipment with cheap labour. This takes inevitably the country away from the technological frontier and leads to underinvestment in human capital. The most skilled people do not find a convenient job at home and migrate, which causes waste of human capital and social and private investment in it - which the industrialists association Confindustria estimates at $€ 14$ billion, or $0.8 \%$ of GDP in 2015 (Confindustria 2017).

Thus the problem for Italy is not one of economic survival or bailout - as is the case of Greece - but is one of long-term development, as was for Germany in early 2000. Avoiding reforms when they were easier and cheaper - before the crisis - and having to try to implement them when it was more difficult and costlier and after Italy's main competitors - Germany primarily - had successfully reformed, caused the substantial failure of the economic revival of the country.

The consideration of the cases of Germany, Greece, and Italy confirm that Kolodko's criticism of neoliberalism is well placed, but insufficient. Germany proves that reforming the working of the economy at the right time makes a difference, even if the reform is in part along neoliberal lines. ${ }^{12}$ If time is lost and neoliberal reforms are implemented among unfavourable domestic and external circumstances, their effect is negative. However, one cannot forget the fundamental importance of the institutional context and the delicate issue of moral hazard in an institutionally incomplete monetary union of largely sovereign countries.

It is not easy to assess how credible is the threat of moral hazard in the EZ. Politically it is certainly a sensitive issue. Economically it is hardly so. First, the threat that excessive deficits by some countries may cause inflation, whose price would be paid also by balanced countries, contrasts with the effort by the ECB to increase inflation to the threshold of $2 \%$, according to its mandate. Second, Target2 is an integrated and harmonized European payment system and not - as Sinn (2014) and other German economists maintain - a danger to the financial

12 The reform of labour contracts and conditions of the Harz reform is in the neoliberal track. Yet the much more effective reform of the placement system and centres is a fundamental institutional reform address to improve the effectiveness of the labour market and decrease transaction costs (Möller 2016). 
stability of the EZ whose price could be paid by Germany. As the ECB president, Draghi, stressed, most of the movement in Target2 liabilities depends on the ECB asset purchase program and depends on how and where the balances of the purchases of bonds are settled (Draghi 2018). However, if a country were to leave the euro, it would have to settle its Target2 liabilities (Draghi 2017), which would then become an asset for Germany. Third, the institutional construction of the EZ, in spite of its incompleteness, is strong enough to keep moral hazard under control and include well established procedures up to the intervention of the troika. Greece teaches that these instruments are effective in their own effect and through the signs and messages they send to markets. Yet Greece is a tiny economy and politically weak country. Effectively disciplining a larger country may be different.

\section{THE NEW PRAGMATISM}

The construction of the EZ disregarded the fundamental issue that, with institutional differences in a monetary union without a political union, flexible and pragmatic policies are needed to avoid asymmetric consequences. Indeed, both fiscal and monetary policies work differently and have dissimilar effects compared to what is foreseen in the neoliberal-ordoliberal EZ paradigm. The distance from a benchmark (usually the best performing country or the EZ requirements) can be measured (OECD 2008). The distance stresses that the same institutions or policies may be dysfunctional for different countries if not compensated in some way. Since monetary institutions and policies are unique, ${ }^{13}$ solution or compensation must be found elsewhere.

Systemic idiosyncrasies cum mainstream austerity policies, given the EZ incompleteness and asymmetry, have imposed extraordinary costs and difficulties to the more distant countries. The outcome is a growing segmentation of the EZ (Dallago 2016a), which fuels political reaction (“populism” and more recently nationalism) and makes reforms (both national and common), convergence and growth more difficult.

Kolodko offers interesting ideas and proposals to solve the problems. The management of the Greek crisis and its comparison with the failed shock therapy in Poland first and the successful "Strategy for Poland" then may provide important suggestions, but the differences between the two cases have to be taken into

13 Yet the depreciation of the euro in summer 2014 had more beneficial consequences for some countries than for others (EC 2015). Also the quantitative easing program of the ECB played an important role in limiting the spread of interest rates within the union. 
account. For years, Greece and other vulnerable countries played an easy but dangerous game with resilient countries and in particular with Germany, to the apparent advantage of both parties. Indeed, “...it takes two to tango. And both Germany and Greece were all for it. One country's surplus becomes another country's deficit; the richer one's receivables become the poorer one's debt; the propensity to lend to someone stronger corresponds to the willingness to borrow from somebody weaker." (Kolodko 2016a: 48) Yet the crisis put an end to the dance and a new issue became fundamental after the opportunity for a cooperative solution was lost when the Papandreu government entered office. ${ }^{14}$ If moral hazard is a serious issue - as many think it is in Germany and other resilient countries - any decision concerning Greece has to take into account the consequences it has in other vulnerable countries, particularly those with a high sovereign debt.

Kolodko's answer to this question is double. First, he is "aware that giving help to Greece in the form of a conditional write-off of part of its debt involves a risk of demonstration effect. Others may demand similar solutions - countries that are structurally weak, struggling with deficit and excessive public debt... when dragging Greece from the economic mire in which it has found itself, EU must have in place a tough and effective EU policy towards other countries, so that with reasonable support they can themselves handle the crisis processes that plague them.” (Kolodko 2016a: 58)

This explanation is sound, yet lacks something. The political process of decision making is complex and hardly fully rational. It is also subject to contrasting interests. There is a question of the distribution of the costs and advantages of any EU decision among countries that have different levels of involvement in the concerned country. Moreover, there is also a delicate question of different domestic perceptions, understanding and moods and their effects on national governments. Collective action is always difficult under these conditions and the first mover risks to get the greatest disadvantage. It is a question of leadership and unfortunately no country is willing to take on the responsibility of leadership in the EZ

14 Upon inauguration on 6 October 2009, Papandreou's government revealed that the yearly public deficit was $12.7 \%$ of GDP, well above the $3 \%$ foreseen in the convergence parameters and much higher than what had been previously officially reported. This led agencies to lower the country's debt rating to $\mathrm{BBB}+$, the lowest in the Eurozone. The government enacted rapidly an austerity program that Eurozone authorities criticized as insufficient. Papandreou went then to officially ask the EU to activate an extraordinary support mechanism, also involving the IMF. While the subsequent negotiations made clear that heavy conditions were attached to the support, in an attempt to solve the heavy political crisis Papandreu announced a referendum to be held at the end of 2011 on the acceptance of the terms of the bailout deal. However, the referendum plan was cancelled, following heavy criticism by the EU, and the government resigned soon. 
(Tamborini 2015). The EZ was so far unable or unwilling to find a solution to this strategic problem that would allow to follow Kolodko's sensible proposal and allow the EZ to get finally rid of the inconclusive and costly game it has followed for too many years.

To give credibility to action, the EZ should find a way to elude the negative consequences of missing leadership and avoid moral hazard. Again, neither neoliberal, nor ordoliberal recipes or views may solve these problems in an institutionally differentiated monetary union. This can be done through a compromise between the involved parties - Greece and the others, in particular Germany "not built on trust but on verification" (Kolodko 2016a: 55). ${ }^{15}$ This is reasonable, but it is not clear in what this method differs from what is used by the EU and EZ through convergence criteria or stabilization plans.

Yet the EZ should offer additional instruments, in particular the sense of a common destiny and mutual solidarity. This should offer a sounder and simpler basis for reaching a compromise, provided that policy approaches also change. The latter would happen when the economic policy follows the theoretical premises of the New Pragmatism. New Pragmatism, according to Kolodko (2014: 140), means an approach "that favours multiculturalism and comes from a system of values that promotes participatory globalisation, inclusive institutions, social cohesion, and sustainable development.” This is appealing and fair, yet projected in the long run and with unclear concern for the critical issue of institutional differences in the monetary union.

When based on the New Pragmatism, the crucial dichotomy in shaping the future of modern capitalism will be not the rivalry between neoliberal capitalism and state capitalism, but the confrontation of these with social market economy (Kolodko 2017a). "The New Pragmatism calls for a well-balanced role of the state and a supra-state economic policy coordination, which is meant to correct, or, when necessary, to strengthen market processes.” (Kolodko 2014: 155) It is apparently clear that the state should be different compared to the neoliberalist state: stronger, more professional and directly interested in the effective working of the market economy to the advantage of society at large. It should avoid playing allocative functions, refrain from socializing private losses, show concern for the fundamental shortcomings of the market and remedy overly unequal income distribution. Similarly, also business should be not only profitable, but also follow legal and ethical principles.

These should be the values at the basis of European integration, as the treaties stipulate - in particular Article 2 of the Lisbon Treaty. It seems inevitable that

15 This was said by President Obama when the deal that solved the conflict situation around Iran's nuclear program was struck. 
the action of enlightened elites, however important, is not sufficient and strong popular support is needed through active political participation. Kolodko is right in stressing repeatedly that the elitist neoliberal approach to globalization and European integration, and even more so the Monetary Union, was more concerned with lobbies than with giving a sound popular base to the processes. Yet neoliberal shortcuts may be appealing also to the society at large.

In pursuing these goals, the EU should play a better role, in particular in the case of distress and crisis of member countries: "More EU-wide policy coordination is badly needed and ought to be welcomed as well as further fiscal consolidation by cutting expenses and raising taxation, but it won't be enough to overcome the crisis. An unorthodox crisis calls for unorthodox action.” (Kolodko 2016b: 8-9) An example of unorthodox actions is to mobilize resources that exist, but are left idle for active policy making. "There is not only mountainous public debt, but also giant - in many cases excessive - government financial reserves, mainly in the form of foreign exchange reserves. After all, these are provisions made for hard times. ..." (Kolodko 2016b: 9).

Why do such reserves remain idle? "The problem (...) is that resorting to such symmetrical reduction of state reserves and public debt, as well as a great redistribution of financial stocks and flows, is clearly detrimental to the interests of the financial lobby.” (Kolodko 2016b: 2) In fact, foreign exchange reserves are located primarily in debt securities of Western countries and placed on short-term deposits in Western banks. However, it should be noted that such reserves exist also to support the currency and give credibility to the country in its financial and foreign trade operations. In a monetary union, such reserves are important as a buffer against national moral hazard by giving credible support to national commitments.

It seems that, after all, the EZ has to abandon the neoliberal-ordoliberal approach and take seriously institutional and structural differences and adapt parameters and policy making to equalize such differences. Flexibility of parameters and the consideration of exceptional circumstances are but a timid, albeit pragmatic move in the right direction. Faster and bolder - pragmatic but also institutional - action is dramatically needed and the idea of the New Pragmatism is precious in this perspective.

\section{CONCLUSIONS: THE WAY FORWARD}

Many of Kolodko's proposals refer to the need for a new policy approach to deal with the problems of an ungoverned globalization and with the transformation process in Central-Eastern Europe. Yet they have a more general meaning and 
can be transformed into lessons of more general value (Kolodko 2009). They are directly and indirectly useful also to the EZ. However, also country studies and their comparison, in particular of Poland and Greece, provide useful hints and teachings.

Kolodko's proposals can be distinguished into three related groups: a) the criticism of the dominant neoliberal view and policy making and their strict link to financial lobbies; b) the need for a new theoretical and practical approach to policy making, coupled with learning from experience, combining social and economic equity with economic efficiency; and c) the need for active policy management, in particular for growth and industrial policies. The leading ideas for these proposals are that the neoliberal approach is wrong in itself and leads to wrong policies and that countries, in particular those in transformation, distress or development dramatically need policy support on the demand side and growth policies (Kolodko 2003).

The proposals open three questions in a monetary union.

(i) If the danger of moral hazard exists and is perceived as important at least by some partners in a monetary union, how could it be kept at bay within the New Pragmatism perspective? Which solutions could assure that the latter approach is superior to the neoliberal approach not only in promoting equity and growth, but also in curbing internal threats to inter-country cooperation?

(ii) Given the institutional differences within the EZ, which policies are important on the demand side? Would any support to demand - via increasing incomes or decreasing taxation or public works - do good or would particular policies, e.g. infrastructural investment policies, be preferable?

(iii) Given the existence of inefficient national institutions and organizations (e.g. public administrations) and high transaction costs (e.g. from bureaucracy), would demand policies play a useful role or would policies and reforms on the supply side be a necessary precondition?

Kolodko makes useful and reasonable proposals and suggests that some kind of action on the supply and institutional sides are necessary. Yet the relation between the two remains insufficiently specified. Many economists agree that greater attention must be paid to cultural conditions and social contexts and the targets of development have to be redefined. Although this gives due relevance to informal institutions, it is a long-run program that requires the support of shorter term effective solutions for answering the present, pressing problems of countries and the EZ.

Reforms are dramatically needed in the EZ. The process of European integration is in serious crisis; threats of disruption loom around. While in summer 2015 it looked as if the Greek affair could be the final drama of the EU existence, 
it is now apparently on a safe ground. Also the unexpected event of Brexit is somehow moving ahead more to the disadvantage of Great Britain than the EU. However, new threats loom around. Some are external, notably the protectionist threats by the Trump administration in the United States and the continuing turmoil and tensions on the Southern and Eastern rims of the EU. However, the critical threats are internal and require fast and effective answers, along with long-run perspectives and reforms.

It seems that common institutions and organizations are progressively pushed to the background, while national governments are taking over increasing slices of their sovereignty in a less and less cooperative perspective, including in the case of budget deficits. The common EU institutions and governance are weakening. Particularly outspoken have been the governments of the four Visegrád countries, which by now apparently form a particularly critical and sometimes openly adverse coalition, consistently contrasting the Commission proposals on selected issues, notably the management of immigration.

The situation is apparently different in the EZ. While the conditions attached to the common currency have been the target of growing criticism in recent years, in fact it appears to be solid. Even political parties which, in opposition, urged the exit from the EZ - such as the Liga and the 5 Stars movement in Italy - became more prudent once in government. Yet problems continue to accumulate, difficulties in some countries are not solved and cohesive forces are shaken and weakened, in spite of the recent revival of EU economies. In a traditional fashion, opposition becomes outspoken when the perception that the worst is over becomes more solid.

There are always dangers in change that should be taken in due consideration. Removing the dominant policy paradigm and move towards a more expansionary stance may present problems for rebuilding trust in the EZ by avoiding moral hazard and for solving structural problems, such as making public administrations more efficient and friendly to citizens and business and balance the lobbies' power. Consequently, changing effectively policies needs three preconditions: a) change policy priorities, which requires political decisions and institutional changes; b) make policy making more efficient and effective, which requires political determination and domestic reforms conditioned by available resources; and c) make the economic and monetary union institutionally more complete, less bureaucratic and more attentive to intercountry institutional differences.

These changes have a different time horizon and require different implementation instruments and processes. In any case, the frame of a broader and longer term perspective is fundamental. Kolodko's criticism and proposals give a useful contribution to its definition. 


\section{REFERENCES}

Baldwin, R. - Wyplosz, C. (2012): The Economics of European Integration. 4th edition, New York: McGraw Hill.

Bini Smaghi, L. (2010): Slaves of Defunct Economists. Speech at the Master Programme in International Business and Economics, Università di Pavia, 24 February (https://www.ecb.europa.eu/ press/key/date/2010/html/sp100224.en.html)

Blanchard, O. - Leigh, D. (2013): Growth Forecast Errors and Fiscal Multipliers. IMF Working Paper, WP/13/1, January.

Bonefeld, W. (2012): Freedom and the Strong State: On German Ordoliberalism. New Political Economy, 17(5): 633-656.

Bonefeld, W. (2013): German Neoliberalism and the Idea of a Social Market Economy. Journal of Social Sciences, Pre-print, Phitsanulok, Thailand.

Cohn, T. H. (2012): Global Political Economy. Theory and Practice. Boston: MA: Longman, 6th edition.

Confindustria (2017): Le sfide della politica economica. Scenari economici (The Challenges of Economic Policy. Economic Scenarios). September, No. 30, Rome Centro Studi Confindustria (http:// www.bollettinoadapt.it/wp-content/uploads/2017/09/ScenariEconomici_settembre_2017.pdf)

Dallago, B. (1996): Investment, Systemic Efficiency and Distribution. Kyklos, 49(4): 615-641.

Dallago, B. (2016a): One Currency, Two Europe. Singapore: World Scientific Publishing Co.

Dallago, B. (2016b): The Future of European Integration and Brexit: Is Brexit only Brexit? Acta Oeconomica, 66(S): 113-138.

Da Rold, V. (2018): Il debito greco, una lunga storia di errori (The Greek Debt. A Long History of Mistakes). Il Sole 24 Ore, 2 July.

Draghi, M. (2017): Letter from the ECB President to Mr Marco Valli and Mr Marco Zanni, Members of the European Parliament. Frankfurt, 18 January (https://www.ecb.europa.eu/pub/pdf/ other/170120letter_valli_zanni_1.en.pdf)

Draghi, M. (2018): Press Conference. Frankfurt am Main, 26 July 2018 (https://www.ecb.europa. eu/press/pressconf/2018/html/ecb.is180726.en.html)

Dullien, S. - Guerot, U. (2012): The Long Shadow of Ordoliberalism: Germany's Approach to the Euro Crisis. European Council on Foreign Relations, Policy Brief, No. 49, February.

EC (2015): European Economic Forecast. European Economy. Winter 2015, No. 1. Brussels, Directorate-General for Economic and Financial Affairs (http://ec.europa.eu/economy_finance/ publications/european_economy/2015/pdf/ee1_en.pdf)

EC (2016): Towards a Positive Fiscal Stance for the Euro Area. Communication from the Commission to the European Parliament, the Council, the European Economic and Social Committee and the Committee of the Regions. Brussels, 16.11.2016 COM(2016) 727 final (https:// ec.europa.eu/info/publications/2017-european-semester-communication-fiscal-stance_en)

EC (2017): Monitoring the Application of European Union Law. Annual Report 2016. Brussels, (https://ec.europa.eu/info/sites/info/files/file_import/EU28_factsheet_2016_en_0.pdf)

Giavazzi, F. - Pagano, M. (1990): Can Severe Fiscal Contractions Be Expansionary? Tales of Two Small European Countries. NBER Macroeconomics Annual, Vol. 5, pp. 75-111.

Kolodko, G. W. (2003): Transition to a Market and Entrepreneurship: Systemic Factors and Policy Options. In: McIntyre, R. J. - Dallago, B. (eds): Small and Medium Enterprises in Transnational Economies. Houndmills, Basingstoke and Helsinki: Palgrave Macmillan and WIDER, pp. 153-170. 
Kolodko, G. W. (2009): Poland's Great Transformation and the Lessons to be Learnt. In: Dallago, B. - Blokker, P. (eds): Regional Diversity and Local Development in the New Member States. Houndmills, Basingstoke: Palgrave Macmillan, pp. 99-121.

Kolodko, G. W. (2010): Neoliberalism, the Global Crisis, and the Ways Out. Rivista di Politica Economica, July-September: 1-14.

Kolodko, G. W. (2014): The New Pragmatism, or Economics and Policy for the Future. Acta Oeconomica, 64(2): 139-160.

Kolodko, G. W. (2016a): How to Destroy a Country: The Economics and Politics of the Greek Crisis. Rivista di Politica Economica, April-June: 37-61.

Kolodko, G. W. (2016b): Causes, Mechanisms and Implications of Grexit: Its Politics and Economics. TIGER Working Paper Series, No. 133, September.

Kolodko, G. W. (2017a): New Pragmatism versus New Nationalism. TIGER Working Paper Series, No. 137, April.

Kolodko, G. W. (2017b): Economics and Politics of the Currency Convergence: The Case of Poland. Communist and Post-Communist Studies, 50: 183-194.

Möller, J. (2016): The Future of the German Model after the Labour Market Reforms. In: Dallago, B. - Guri, G. - McGowan, J. (eds): A Global Perspective on the European Economic Crisis. Abingdon, Oxfordshire: Routledge, pp. 162-178.

Nuti, D. M. (2013): Perverse Fiscal Consolidation. Paper presented at the International Conference on Economic and Political Crises in Europe and the United States: Prospects for Policy Cooperation, Trento, 7-9 November.

Obstfeld, M. - Shambaugh, J. C. - Taylor, A. M. (2004): The Trilemma in History: Tradeoffs among Exchange Rates, Monetary Policies, and Capital Mobility. NBER Working Paper Series, No. 10396, March (http://www.nber.org/papers/w10396)

OECD (2008): Handbook on Constructing Composite Indicators. Methodology and User Guide. Paris: OECD and Ispra, Italy: Joint Research Centre (JRC) of the European Commission (http:// www.oecd.org/sdd/42495745.pdf)

Podkaminer, L. (2016): Economic Disintegration of the European Union: Unavoidable but Probable. Acta Oeconomica, 66(S): 49-61.

Schnyder, G. - Siems, M. (2013): The Ordoliberal Variety of Neoliberalism. In: Konzelmann, S. J. - Fovargue-Davies, M. (eds): Banking Systems in the Crisis: The Faces of Liberal Capitalism. Abingdon: Routledge, pp. 250-268. (http://papers.ssrn.com/sol3/papers.cfm?abstract_ id $=2142529$ )

Sinn, H. W. (2014): The Euro Trap. On Bursting Bubbles, Budgets, and Beliefs. Oxford: Oxford University Press.

Stiglitz, J. E. (2014a): Europe’s Austerity Zombies. Project Syndicate, 26, September (http://www. project-syndicate.org/print/joseph-e-stiglitz-wonders-why-eu-leaders-are-nursing-a-deadtheory)

Tamborini, R. (2015): EMU 2.0 and the German Problem. In: Dallago, B. - McGowan, J. (eds): Crises in Europe in the Transatlantic Context: Economic and Political Appraisals. Abingdon, Oxfordshire: Routledge, pp. 194-200.

Young, B. (2014): German Ordoliberalism as Agenda Setter for the Euro Crisis: Myth Trumps Reality. Journal of Contemporary European Studies, 22(3): 276-287.

Zoppè, A. (2018): Implementation of the Macroeconomic Imbalance Procedure: State-of-Play. European Parliament, Economic Governance Support Unit, May (http://www.europarl.europa.eu/ RegData/etudes/IDAN/2016/497739/IPOL_IDA(2016497739_EN.pdf) 